\title{
Net Exports, Consumption Volatility and International Business Cycle Models *
}

\author{
Andrea Raffo ${ }^{\dagger}$ \\ Federal Reserve Bank of Kansas City
}

September 2006

\begin{abstract}
Conventional two-country RBC models interpret countercyclical net exports as reflecting, in large part, the dynamics of capital. I show that, quantitatively, theoretical economies rely on counterfactual terms of trade effects: trade fluctuations, on the contrary, are driven primarily by consumption smoothing, thus generating procyclical net trade in goods. I then consider a class of preferences that embeds home production in a reduced form: consumption volatility increases so that countercyclical net exports reflect primarily a strong relation between income and imports, as in the data. The major discrepancy between theory and data concerns the variability of international prices.
\end{abstract}

JEL Classification: E32; F32; F41

Keywords: Net Exports; International Business Cycles; Home Production; Consumption Volatility

${ }^{*}$ I would like to thank my advisor Andy Atkeson for encouragement and advice provided at all stages of this research. I am also grateful to Ariel Burstein, Hal Cole, Luca Dedola, Eduardo Ganapolsky, Lee Ohanian, Fabrizio Perri, Randall Wright and seminar participants at Arizona State University, ECB, Kansas City FRB, Midwest Macroeconomic Conference, 2005 EEA Meetings, Rice University, 2005 SCIEA Meetings, 2006 SED Meetings, UCLA and UMD for helpful comments. Part of this project was conducted while visiting the Research Department at the Atlanta FRB whom I thank for their hospitality and useful suggestions. Financial support from UCLA's Dissertation Year Fellowship is gratefully acknowledged.

${ }^{\dagger}$ Correspondence: Andrea Raffo, Economic Research Department, Federal Reserve Bank of Kansas City, 925 Grand Blvd, Kansas City, MO, 64198. Email: andrea.raffo@kc.frb.org. The views expressed herein are solely those of the author and do not necessarily reflect the views of the Federal Reserve Bank of Kansas City or the Federal Reserve System 


\section{Introduction}

Countercyclical net exports represent a central feature of international data, uniformly shared by small and large countries, both developing and developed. This property indicates that countries borrow from international capital markets during booms and repay in recessions, which is at odds with the predictions of consumption smoothing theory.

In several articles, Backus-Kehoe-Kydland [1992, 1994] (BKK henceforth) show that twocountry RBC models are consistent with various properties of international fluctuations, and specifically, countercyclical net exports. Countercyclical trade fluctuations, in their interpretation, reflect in large part the dynamics of capital formation: expansions are associated with investment booms financed by borrowing from international capital markets ${ }^{1}$. Since then, the BKK set up has become a benchmark model in the open macroeconomic literature and variations of it have been extensively used to address issues related to international comovements, role of asset market incompleteness and relative price fluctuations ${ }^{2}$.

This paper argues that the mechanism by which the BKK model generates countercyclical net exports is counterfactual. After decomposing the cyclical movements of net exports into price and quantity fluctuations, I show that in the BKK model large changes in international prices (terms of trade effect) generate countercyclical net exports. In the data, on the contrary, countercyclical net exports are associated with fluctuations in the (net) quantity of goods traded across countries, while international prices play a minor role.

Countercyclical net exports have a counterpart in terms of volatilities: the volatility of domestic spending is larger then the volatility of output. In light of this interpretation, I document that in the BKK model domestic spending is systematically less volatile than output. Throughout the analysis, I include adjustment costs to investment to avoid the volatility of domestic spending from being artificially increased through this channel. Hence, after reproducing the volatility

\footnotetext{
${ }^{1}$ For an early discussion on the relationship between investment and current account, see Sachs [1981].

${ }^{2}$ See, for example, Chari et al. [2002], Kehoe and Perri [2002], Heatcote and Perri [2002, 2004], Corsetti, Dedola and Leduc [2004].
} 
of investment observed in the data, my findings suggest that the BKK model delivers too little volatility in consumption. In other words, and once again, consumption smoothing is the prevailing force governing the dynamics of international trade in the model.

I then consider a class of preferences, proposed by Greenwood, Hercowitz and Huffman [1988] (GHH preferences), that include home production in a reduced form. Introducing home production in the BKK framework generates sufficient volatility in consumption so that domestic spending is more volatile than output. Countercyclical net exports are associated with import of goods exceeding export when income rises, as in the data.

An extensive literature has documented that the interaction between home and market activities has important quantitative implications for business cycle predictions of DSGE models ${ }^{3}$. Supported by evidence on the allocation of time and on the cyclical fluctuations in the consumption of market goods that are substitutes for home production (for example, eating at restaurants, housecleaning, child care...), these studies incorporate the idea that households substitute between home and market activities depending on the wage rate. High wages during economic expansions are associated with an increase of hours worked in the market and a corresponding reduction in home production. As a consequence, households increase their consumption of market goods.

Our previous discussion suggests that the home production structure implicit in the GHH preferences is a promising way to deal with the lack of variability in consumption implied by standard isoelastic preferences. My results confirm that quantitatively this is indeed the case. Moreover, sensitivity analysis shows that these findings are robust to a wide range of parameter values. I study the effects of varying the elasticity of substitution between traded goods, which turns out to be critical in the BKK model. Intuitively, high complementarity between traded goods implies that country-specific productivity shocks, by altering the relative scarcity of goods in international markets, produce strong terms of trade effects. As argued before, in the original BKK formulation this change in the relative price of traded goods translates into countercyclical

\footnotetext{
${ }^{3}$ See, for example, Benhabib et al. [1991], Greenwood et al. [1988], McGrattan et al. [1997]. Baxter and Jermann [1999] show that home production helps explaining the excessive sensitivity of consumption to predictable changes in income.
} 
net exports. With GHH preferences instead, the model relies on a mechanism that involves directly larger response of market consumption to shocks and, as a consequence, the value of this elasticity does not affect the cyclical properties of net exports.

I finally analyze the effects of varying country size. Countercyclical net exports represent a feature of the data consistent across countries, independently of their size. Motivated by this observation, I study an economy in which a small country trades with a larger country, proxy for a rest of the world aggregate. This model exacerbates the failures of the benchmark case in that consumption smoothing even dominates the terms of trade effect: net exports are thoroughly procyclical. Introducing the tradeoff between home and market activities through GHH preferences produces countercyclical net exports independent of country size, as in the data.

The structure of the paper is as follows. Section II presents the main international business cycle features, focusing on the cyclical behavior of net exports and terms of trade. Section III presents the BKK model and Section IV provides a discussion about its counterfactual implications for the dynamics of international trade in goods. Section V introduces GHH preferences in the BKK setup. It illustrates how home production provides a mechanism to increase the volatility of (market) consumption and delivers countercyclical net exports without relying on changes in international prices. This section also discusses the sensitivity of the results to changes in parameter values. Section VI concludes.

\section{Data}

This section documents the main properties of international business cycle data, focusing on the dynamic of trade variables. I follow the tradition of the international macroeconomic literature in defining the terms of trade as the relative price of imports to exports. Data for most countries are from OECD's Quarterly National Accounts database. In what follows, all statistics refer to the residual component obtained after applying HP-filter with smoothing parameter equal to 1600 to the natural logarithm of each series. The only exception is net exports, for which no logarithm transformation is implemented. 
The first column of Table 1 presents the contemporaneous correlation between net exports to GDP ratio and output for most OECD countries, where both variables are measured at current prices. The second column of the table reports the same correlation for emerging economies as documented in Aguiar and Gopinath [2004] and Neumeyer and Perri [2005].

Table 1. Correlation Between Net Exports and Output

\begin{tabular}{|c|c|c|c|}
\hline \multicolumn{2}{|c|}{ Developed Economies } & \multicolumn{2}{|c|}{ Emerging Economies } \\
\hline Australia & -0.36 & Argentina & -0.89 \\
\hline Belgium & -0.18 & Brazil & -0.03 \\
\hline Canada & -0.17 & Ecuador & -0.79 \\
\hline Finland & -0.27 & Israel & 0.12 \\
\hline France & -0.41 & Korea & -0.86 \\
\hline Germany & -0.07 & Malaysia & -0.74 \\
\hline Greece & -0.39 & Mexico & -0.87 \\
\hline Italy & -0.27 & Peru & -0.24 \\
\hline Japan & -0.40 & Philippines & -0.40 \\
\hline Netherlands & -0.15 & Slovak Republic & -0.44 \\
\hline Norway & -0.01 & South Africa & -0.54 \\
\hline Spain & -0.38 & Thailand & -0.83 \\
\hline Sweden & -0.04 & Turkey & -0.69 \\
\hline Switzerland & -0.21 & & \\
\hline UK & -0.52 & & \\
\hline US & -0.49 & & \\
\hline EU-15 & -0.54 & & \\
\hline Aver: & & -0.40 & \\
\hline Medi & & -0.39 & \\
\hline
\end{tabular}

Note. Developed Economies: data from OECD-QNA (1980:1-2004:2). Series were filtered using HP filter with smoothing parameter of 1600 .

Emerging Economies: see Aguiar and Gopinath (2004) and Neumeyer and Perri (2005). 
The trade balance is negatively correlated with output in all cases except for Israel, the median correlation value being -0.39 . This property represents a central feature of international data, as noted among others by Sachs [1981], Backus and Kehoe [1992] and Danthine and Donaldson [1993], and it implies that countries borrow from international capital markets during high income periods. This observation is then at contrast with the quantitative implications of models in which consumption smoothing is the dominant force driving the dynamics of quantities.

In addition, Table 1 confirms that countercyclical net exports are a general property of the data that does not depend on country size. Small economies such as Canada (-0.17) or Japan $(-0.40)$ as well as large economies like the U.S. (-0.49) or EU-15 (-0.54) all share this feature of the data.

Table 2 reports for most OECD countries international business cycle statistics of interest for our analysis. The first four columns present the standard deviation of consumption (C), government expenditure (G), investment (I) and domestic absorption (DA) relative to the standard deviation of output. The remaining three columns show the correlation with output of net exports over GDP (NX), the terms of trade (TOT) and net exports over GDP measured at constant prices (NXQTY). This last variable measures the difference between quantities of goods exported and quantities of goods imported using a common fixed numeraire and can be interpreted as a proxy for real net trade of goods between countries.

Some interesting empirical regularities emerge. First, by definition net exports equal the difference between output and domestic absorption. It then follows that countercyclical net exports have a counterpart in terms of volatilities: domestic absorption has to be more volatile than output. The data confirms this intuition in that the ratio between the standard deviations of domestic absorption and output is in all cases greater than one.

The other statistics in terms of volatilities document the usual business cycle facts reported elsewhere in the literature, such as in Backus and Kehoe [1992]. Investment is more or less three times more volatile than output, the median value being 2.87. Private consumption and government consumption volatilities are similar in terms of magnitude: average and median values show 
that consumption is 0.85 times as volatile as output. Considering that the investment share of output is about twenty percent, these statistics altogether indicate that a large part of the volatility in domestic absorption originates from consumption. This observation will play an important role in the analysis: theoretical economies need to generate a substantial degree of variability in consumption at business cycle frequencies.

Table 2. Business Cycles Statistics

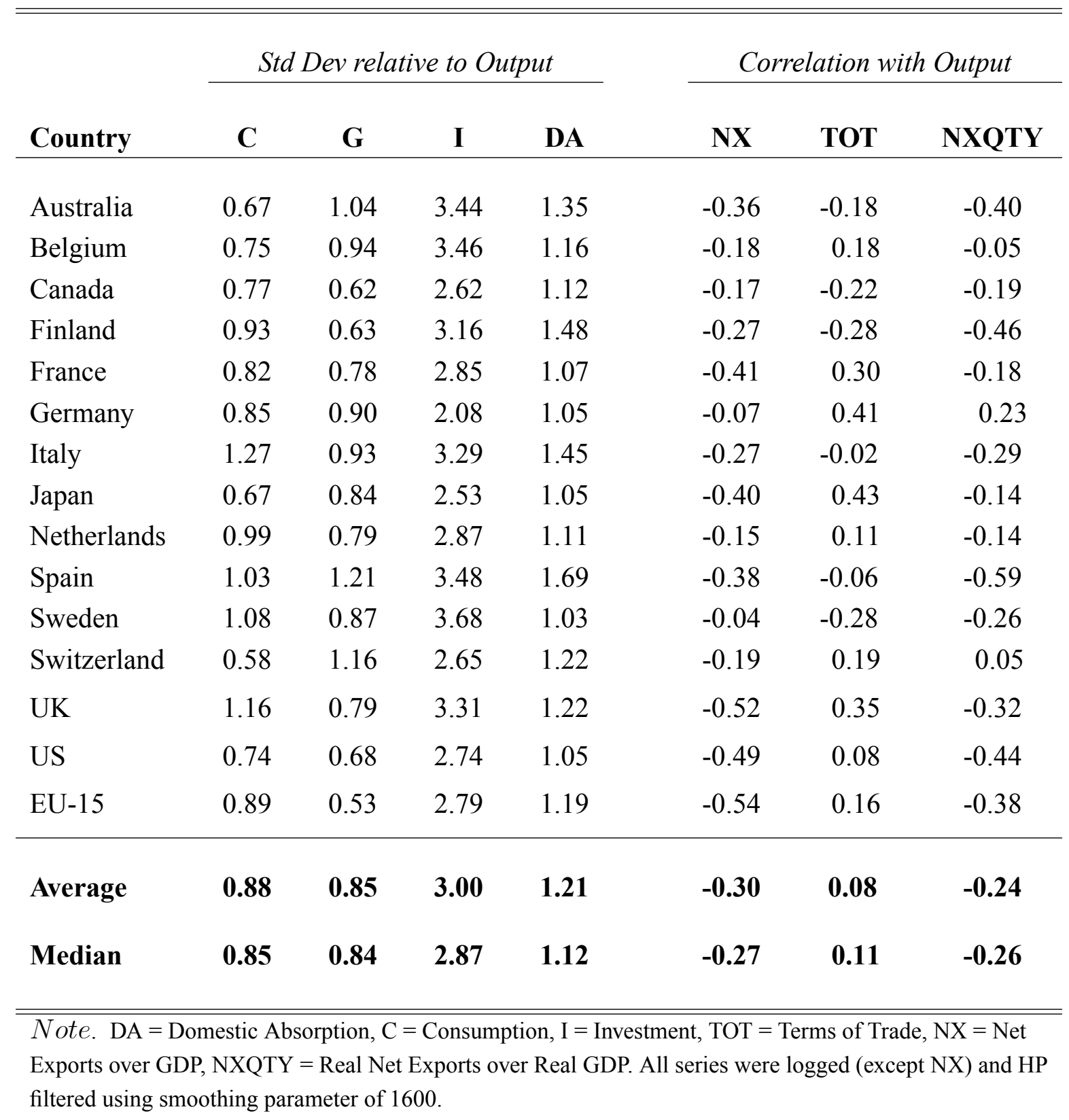


The right section of the table shows the cyclical properties of our variables of interest, the terms of trade and net exports. The correlation between the terms of trade and output is slightly positive, the median correlation being 0.11 with values ranging from -0.28 to 0.43 . In addition, country-wise this correlation calculated using 20-quarters rolling window varies in sign over time ${ }^{4}$. These observations suggest that the terms of trade do not have significant pattern over the cycle. On the other hand, both net exports (NX) and real net exports (NXQTY) are negatively correlated with output, indicating that real imports of goods and services exceed exports during expansions.

In summary, the data show three main patterns that characterize international business cycles. First, net exports are countercyclical, indicating that countries borrow from international capital markets during expansions. Second, or alternatively, domestic absorption is more volatile than output with a large fraction of this volatility originating from consumption variability. Third, the real net trade in goods across countries is negatively correlated with output while the terms of trade do not have a strong cyclical pattern. In other words, there is a strong relation between income and imports of goods.

\section{The Model}

\subsection{Preferences and Technology}

Time is discrete. Denote by $s_{t}$ an event drawn each period from a (possibly infinite) set $S_{t}$, by $s^{t}$ the history of events up to date $t$ and by $\pi\left(s^{t}\right)$ the probability at time 0 of a particular history $s^{t}$.

There are two countries $(i=1,2)$ populated by identical infinitively lived agents. Countries might differ in terms of their relative size and $\Pi_{i}$ indicates the measure of each country. There are two intermediate goods $(j=A, B)$ and two final goods $\left(C_{i}\right)$. Each country specializes in the production of one intermediate good and factors of production are immobile across countries.

Households derive utility from consumption and leisure. Preferences are of the standard

\footnotetext{
${ }^{4}$ Tables are available upon request.
} 
isoelastic form

$$
U\left(C_{i}\left(s^{t}\right), 1-N_{i}\left(s^{t}\right)\right)=\frac{\left[C_{i}^{\mu}\left(s^{t}\right)\left(1-N_{i}\left(s^{t}\right)\right)^{1-\mu}\right]^{1-\gamma}}{1-\gamma}
$$

where $C_{i}$ is consumption, $N_{i}$ is labor and the time endowment is normalized to one.

Households supply labor and rent capital to firms producing intermediate goods in a perfectly competitive market. Intermediate good producers solve a standard profit maximization problem subject to a Cobb-Douglas production constraint, that is

$$
\operatorname{Max} \Pi_{i}\left(K_{i}\left(s^{t}\right), N_{i}\left(s^{t}\right)\right)=q_{i}^{j}\left(s^{t}\right) e^{z_{i}\left(s^{t}\right)} F\left(K_{i}\left(s^{t}\right), N_{i}\left(s^{t}\right)\right)-W_{i}\left(s^{t}\right) N_{i}\left(s^{t}\right)-R_{i}\left(s^{t}\right) K_{i}\left(s^{t}\right)
$$

s.t.

$$
F\left(K_{i}\left(s^{t}\right), N_{i}\left(s^{t}\right)\right)=K_{i}^{\theta}\left(s^{t}\right) N_{i}^{1-\theta}\left(s^{t}\right)
$$

where $q_{i}^{j}\left(s^{t}\right)$ is the price of the intermediate $\operatorname{good} j$ in country $i$ relative to the final good of country $i, W_{i}\left(s^{t}\right)$ and $R_{i}\left(s^{t}\right)$ are wages and rental rates in final good units, $K_{i}\left(s^{t}\right)$ is capital and $z_{i}\left(s^{t}\right)$ is an exogenous technology shock.

After intermediates are produced, households trade goods in the international market without frictions (hence the law of one price holds) and sell all their holdings of intermediate goods to firms that produce domestic final goods. The final good can be either consumed or invested. In each country, capital is subject to a convex adjustment cost so that it evolves according to the following law of motion

$$
K_{i}\left(s^{t+1}\right)=(1-\delta) K_{i}\left(s^{t}\right)+X_{i}\left(s^{t}\right)+\Psi\left(\frac{X_{i}\left(s^{t}\right)}{K_{i}\left(s^{t}\right)}\right) K_{i}\left(s^{t}\right)
$$

where $X_{i}\left(s^{t}\right)$ is investment and $\delta$ is the depreciation rate. $\Psi($.$) is such that \Psi^{\prime}()>0,. \Psi^{\prime \prime}()<$.0 . Final good producers are competitive and solve the problem

$$
\operatorname{Max} \Pi_{i}\left(A_{i}\left(s^{t}\right), B_{i}\left(s^{t}\right)\right)=G_{i}\left(A_{i}\left(s^{t}\right), B_{i}\left(s^{t}\right)\right)-q_{i}^{A}\left(s^{t}\right) A_{i}\left(s^{t}\right)-q_{i}^{B} B_{i}\left(s^{t}\right)
$$

s.t.

$$
G_{i}\left(A_{i}\left(s^{t}\right), B_{i}\left(s^{t}\right)\right)= \begin{cases}{\left[\varpi_{i} A_{i}^{1-\alpha}\left(s^{t}\right)+\left(1-\varpi_{i}\right) B_{i}^{1-\alpha}\left(s^{t}\right)\right]^{\frac{1}{1-\alpha}}} & i=1 \\ {\left[\left(1-\varpi_{i}\right) A_{i}^{1-\alpha}\left(s^{t}\right)+\varpi_{i} B_{i}^{1-\alpha}\left(s^{t}\right)\right]^{\frac{1}{1-\alpha}}} & i=2\end{cases}
$$


where $\varpi_{i}>0.5$ determines home bias in the composition of final goods ${ }^{5}$. We denote by $\sigma=\frac{1}{\alpha}$ the elasticity of substitution between intermediate goods $A$ and $B$.

In the benchmark case asset markets are complete. Let $D_{i}\left(s^{t}, s_{t+1}\right)$ be the quantity of bonds purchased by consumer in country $i$ after history $s^{t}$ that entitles to one unit of country 2 consumption if event $s_{t+1}$ happens in period $t+1$. Let $Q\left(s^{t}, s_{t+1}\right)$ be the price of such an asset. Then the budget constraint for the representative citizen of country $i$ is

$$
\begin{aligned}
& C_{i}\left(s^{t}\right)+X_{i}\left(s^{t}\right)+r x\left(s^{t}\right) \sum_{s_{t+1}} Q\left(s^{t}, s_{t+1}\right) D_{i}\left(s^{t}, s_{t+1}\right)= \\
& =W_{i}\left(s^{t}\right) N_{i}\left(s^{t}\right)+R_{i}\left(s^{t}\right) K_{i}\left(s^{t}\right)+r x\left(s^{t}\right) D_{i}\left(s^{t-1}, s_{t}\right)
\end{aligned}
$$

where $r x\left(s^{t}\right)$ denotes the real exchange rate ${ }^{6}$. The household in each country maximizes utility subject to this budget constraint and the law of motion for capital.

I will depart from the complete asset market assumption by considering the case in which agents can trade only a riskless bond. Denote by $D_{i}\left(s^{t}\right)$ the quantity of bonds purchased by the consumer in country $i$ after history $s^{t}$ that entitles with certainty to one unit of (country 2 ) consumption in period $t+1$. Let $Q\left(s^{t}\right)$ be the price of such an asset. The budget constraint for the representative citizen of country $i$ can be expressed as follows

$$
C_{i}\left(s^{t}\right)+X_{i}\left(s^{t}\right)+r x\left(s^{t}\right) Q\left(s^{t}\right) D_{i}\left(s^{t}\right)=W_{i}\left(s^{t}\right) N_{i}\left(s^{t}\right)+R_{i}\left(s^{t}\right) K_{i}\left(s^{t}\right)+r x\left(s^{t}\right) D_{i}\left(s^{t-1}\right)
$$

\subsection{Equilibrium and the effect of country size}

An equilibrium is an allocation and a set of prices for all $s^{t}$ and for all $t \geq 0$ such that, given prices, all agents optimize, both types of firms optimize and markets clear. Market clearing for final goods requires

$$
C_{i}\left(s^{t}\right)+X_{i}\left(s^{t}\right)=G_{i}\left(A_{i}, B_{i}\right) \quad i=1,2
$$

\footnotetext{
${ }^{5}$ The function $\mathrm{G}($.$) is known in the literature as the Armington aggregator.$

${ }^{6}$ Given that bonds are issued in country 2 units of consumption, the real exchange rate does not appear in country 2 budget constraint.
} 
In the complete markets case, bond market clearing requires

$$
\Pi_{1} D_{1}\left(s^{t}, s_{t+1}\right)+\Pi_{2} D_{2}\left(s^{t}, s_{t+1}\right)=0 \quad \forall s_{t+1} \in S
$$

If only a risk-free bond is traded, the market clearing condition for bonds is:

$$
\Pi_{1} D_{1}\left(s^{t}\right)+\Pi_{2} D_{2}\left(s^{t}\right)=0
$$

Intermediate goods market clearing requires

$$
\Pi_{1} A_{1}\left(s^{t}\right)+\Pi_{2} A_{2}\left(s^{t}\right)=F\left(K_{1}\left(s^{t}\right), N_{1}\left(s^{t}\right)\right)
$$

and

$$
\Pi_{2} B_{2}\left(s^{t}\right)+\Pi_{1} B_{1}\left(s^{t}\right)=F\left(K_{2}\left(s^{t}\right), N_{2}\left(s^{t}\right)\right)
$$

In order to solve the model, I first compute the non-stochastic steady state by setting the innovations in productivity equal to their unconditional mean values. I then log-linearize the system of equations characterizing the solution of the model around the deterministic steady state and solve the resulting system of stochastic difference equations using the method of undetermined coefficients as described in Uhlig (1999).

Under complete markets, the only equations in which country size appears are the market clearing conditions for intermediates. The log-linearized version of these two expressions are

$$
e x_{1} \widehat{A}_{2}+\left(1-e x_{1}\right) \widehat{A}_{1}=\widehat{Y}_{1}
$$

and

$$
e x_{2} \widehat{B}_{1}+\left(1-e x_{2}\right) \widehat{B}_{2}=\widehat{Y}_{2}
$$

where a hat denotes percentage changes from steady state for the corresponding variable and $e x_{i}$ $(i=1,2)$ are the export shares of each country. It then follows that:

Proposition 1 With complete asset markets, country size does not affect the equilibrium allocation independently of export shares. 
I will make use of this result by studying the implications of country size on the cyclical properties of net exports. The importance of considering the role of country size is twofold. First, as Table 1 documents, the countercyclicality of the trade balance is a general property and does not depend on country size. Accordingly, theoretical economies need to generate patterns robust to variation in this dimension. Second, this experiment shows that two-country models à la Backus et al. [1994] can be easily adapted to study issues related to international business cycles in small open economy environments. As a matter of fact, small open economies as studied in Mendoza [1991], Correia et al [1995] and Neumeyer and Perri [2005] represent the limiting case of the former in which the size of one country shrinks relative to the other country and the elasticity of substitution between intermediates is very large, that is, only one good is traded internationally. Allowing for more goods to be traded (i.e., having endogenous terms of trade) as in the specification proposed here represents a richer environment of analysis.

I will then conduct all the experiments under two scenarios. The first is the standard BKK symmetric case, which has been extensively studied in the literature as an approximation for trade between U.S. and E.U. The second scenario consists of a small country (Canada) trading with a large country representing the rest of the world (E.U., Japan and U.S.) ${ }^{7}$. The only qualification required by the model to study the effect of country size is that as country size shrinks, openness increases $^{8}$.

Appendix $\mathrm{C}$ reports the parameter values used in the simulation. For the symmetric case, the parameters are taken from the original BKK work. For the small country scenario, the parameters are chosen using similar principles. The interested reader is invited to refer to the appendix for the details.

\footnotetext{
${ }^{7}$ Appendix A provides details about how this aggregate for the rest of the world is constructed.

${ }^{8}$ In the bond economy, country size affects the bond market clearing condition as well.
} 


\subsection{Additional variables of interest}

The following variables will be the focus of the analysis in comparing the quantitative predictions of theoretical economies with the data. The terms of trade are defined as the price of import relative to export

$$
\operatorname{TOT}\left(s^{t}\right)=\frac{q_{1}^{B}\left(s^{t}\right)}{q_{1}^{A}\left(s^{t}\right)}
$$

Net exports over GDP (expressed in terms of final good units) are defined as

$$
N X=\frac{\Pi_{2} q_{1}^{A}\left(s^{t}\right) A_{2}\left(s^{t}\right)-\Pi_{1} q_{1}^{B}\left(s^{t}\right) B_{1}\left(s^{t}\right)}{\Pi_{1} q_{1}^{A} F\left(K_{1}\left(s^{t}\right), N_{1}\left(s^{t}\right)\right)}
$$

Changes in net exports are determined by changes in quantities (exports and imports of goods) and prices (terms of trade). The variable NXQTY represents the difference between exports and imports when both terms are evaluated at steady state prices, that is

$$
N X Q T Y=\frac{\Pi_{2} \bar{q}_{1}^{A} A_{2}\left(s^{t}\right)-\Pi_{1} \bar{q}_{1}^{B} B_{1}\left(s^{t}\right)}{\Pi_{1} \bar{q}_{1}^{A} F\left(K_{1}\left(s^{t}\right), N_{1}\left(s^{t}\right)\right)}
$$

\section{Net Exports and Terms of Trade in BKK}

In this section I show, by use of impulse response analysis and model simulations, that the twocountry international business cycle models generate countercyclical net exports through counterfactually large terms of trade effects. I then argue that this failure is related to the inability of the model to deliver sufficient volatility in domestic spending relative to output. Throughout the analysis, I include adjustment cost to capital so that the volatility of domestic spending is not artificially increased by the excessive responsiveness of investment to productivity shocks. In particular, I adopt a convex adjustment cost function that specifies the units of output foregone to increase the capital stock. This specification introduces an extra parameter, elasticity of the investment-capital ratio with respect to Tobin's $q$, that is calibrated to reproduce the same investment volatility (relative to output) as in the data. Under this parameterization of the adjustment cost function no cost is incurred in maintaining the steady-state capital stock (i.e. in the steady state Tobin's $q$ is one). 


\subsection{Impulse Responses}

Figure 1 presents the impulses responses in country 1 after a 1 percent increase on its own productivity. An increase in productivity has the usual effects of increasing production, consumption and investment. For our purposes, I focus on trade between countries and do not report domestic variables.

Figure 1 decomposes the dynamics of net exports into changes in quantities (NXQTY) and terms of trade effect (TOT). The linearized version of the trade balance provides the mechanics of this decomposition:

$$
\widehat{n x}=i m[\hat{a}-\hat{b}-\widehat{t o t}]
$$

where $\widehat{t o t}$ represents changes in the terms of trade and the first component is obtained from the linearization of net exports evaluated at steady state prices, that is ${ }^{9}$

$$
\widehat{\text { nxqty }}=i m[\hat{a}-\hat{b}]
$$

As shown in the figure, the model does indeed generate countercyclical trade balance ( $N X$ starts from below zero), as originally argued in Backus et al. [1994]. However, this result is entirely due to the strong reaction in the terms of trade. The impulse response of the actual net trade in goods ( $N X Q T Y)$, instead, starts from around zero and stays in the positive region. The intuition for this result is straightforward: positive productivity shocks increase domestic output relative to foreign output, but agents in both countries consume a bundle of both intermediates. When countries trade intermediates in the international market, the relative scarcity of country 2 good is reflected into an increase of the terms of trade. Consequently, net exports become negative during booms because the value of imports increases relative to the value exports. As for quantities, the country is exporting more than importing.

Impulse response analysis, hence, indicates that the model delivers countercyclical net exports through strong terms of trade effects that change the relative value of internationally traded goods. The data, however, show no evidence of such a mechanism.

\footnotetext{
${ }^{9}$ See Appendix B for a full derivation of these expressions.
} 
Fig. 1. BKK : Impulse response for $1 \%$ productivity shock in country 1 . Trade variables.
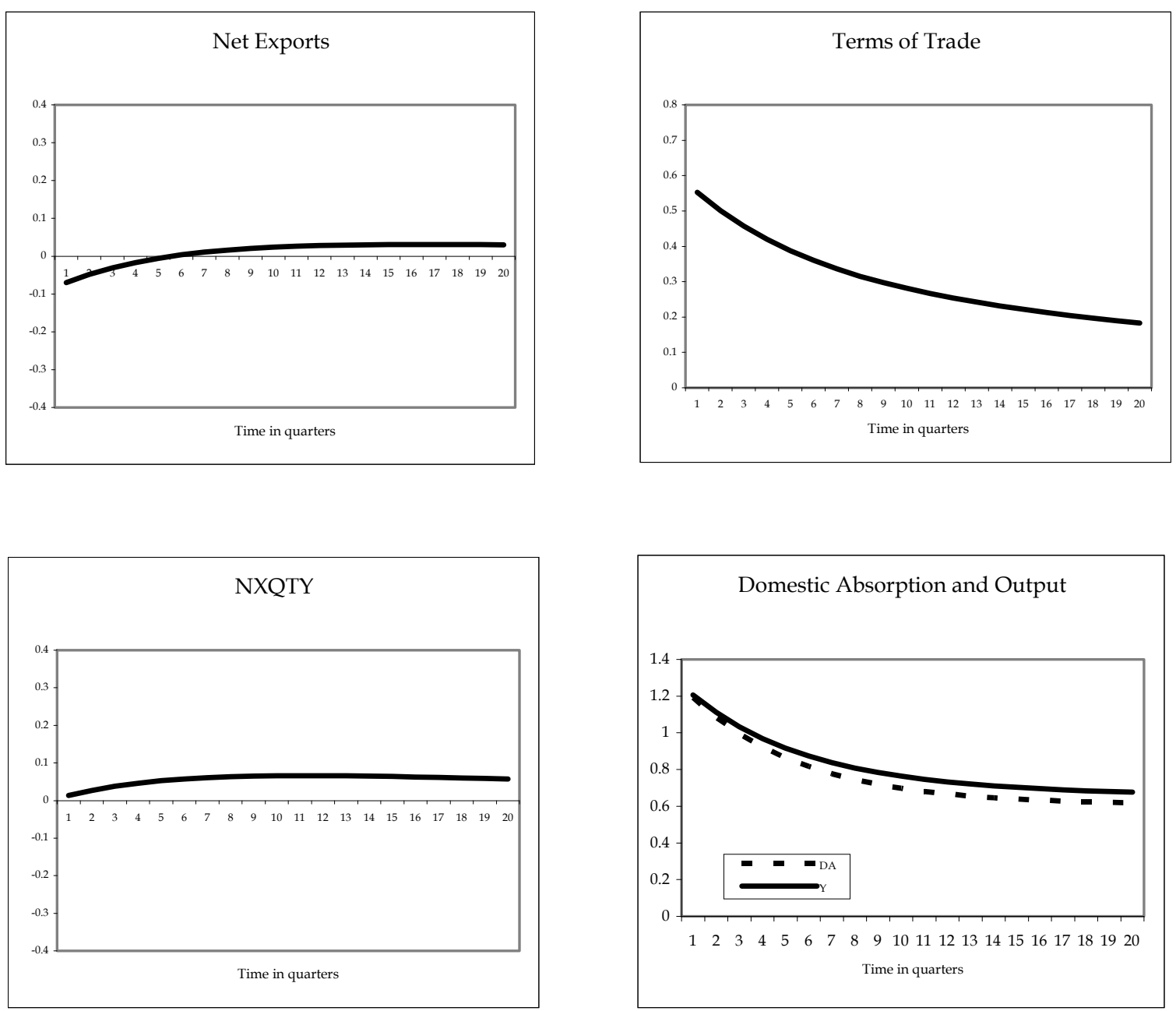

An alternative interpretation on this failure can be obtained from the response of domestic absorption relative to output to productivity shocks (bottom right panel in the figure). As reported in Table 2, countercyclical net exports are associated with domestic absorption being more volatile than output. The impulse response of domestic absorption, however, is below the impulse response of output, which seems to suggest that the model cannot reproduce this property of the data. Simulation results in the next section will confirm this intuition. 


\subsection{Model Simulations}

Table 3 reports the statistics for the variables of interest generated by simulating theoretical economies under a wide range of parameters ${ }^{10}$. The top section of the table refers to the symmetric $\mathrm{BKK}$ case, while the bottom section to the small open economy case.

The first row presents the data. Given the symmetry assumed in the parametrization and in the estimation of the productivity process, we report moments that are averages of U.S and E.U. statistics. Net exports are countercyclical, the correlation with output being -0.51 , which is associated with domestic absorption being more volatile than output (1.12). The terms of trade, on the other hand, do not show any clear cyclical pattern, its correlation with output being close to zero $(0.12)$. The volatility of consumption relative to the volatility of output is 0.81 , denoting a substantial degree of cyclical variability. Investment is somewhat less than three times as volatile as output (2.76).

The remaining rows present simulations for different theoretical economies. Throughout the analysis, I calibrate the parameter governing capital adjustment cost so that all experiments reproduce the volatility of investment (relative to output) observed in the data.

The second row reports the findings for complete asset markets. Net exports are indeed negatively correlated with output (-0.61), but the driving force behind this result is the strong terms of trade effect generated by the change in the relative scarcity of goods across countries. Positive productivity shocks at home increase the production of home goods thus reducing its international value. The subsequent appreciation of the terms of trade makes foreign goods more expensive than home goods, thus generating a negative trade balance mainly because of price effect. However, the net flow of goods between countries $(N X Q T Y)$ is procyclical, which indicates that the trade off between saving (consumption smoothing) and investment (productive opportunities) is resolved in favor of the former. This mechanism is at stark contrast with the data, where

\footnotetext{
${ }^{10}$ Moments for the model are calculated as averages of 100 simulations of series of length 100 periods. HP filter with smoothing parameter of 1600 is applied before computing each statistics. Standard errors are not reported, but available upon request.
} 
expansions are associated with imports exceeding exports.

Our previous discussion provides directions to understand why the model is not consistent with the data: the volatility of domestic spending generated by the model is lower than the volatility of output. This finding is also counterfactual. Provided that we are replicating the volatility of investment observed in the data, these results altogether indicate that the model suffers from excessive smoothness in consumption.

Table 3. Properties of Theoretical Economies

\begin{tabular}{|c|c|c|c|c|c|c|}
\hline \multirow[b]{2}{*}{ BKK } & \multicolumn{3}{|c|}{ Std Dev relative to Output } & \multicolumn{3}{|c|}{ Correlation with Output } \\
\hline & DA & C & I & NX & TOT & NXQTY \\
\hline Data & 1.12 & 0.81 & 2.76 & -0.51 & 0.12 & -0.41 \\
\hline Benchmark & 0.98 & 0.66 & 2.76 & -0.61 & 0.67 & 0.23 \\
\hline Bond Economy & 0.99 & 0.68 & 2.76 & -0.62 & 0.66 & 0.12 \\
\hline Large Elasticity & 0.97 & 0.63 & 2.76 & 0.08 & 0.67 & 0.51 \\
\hline High Persistence & 0.95 & 0.54 & 2.76 & -0.19 & 0.61 & 0.46 \\
\hline Two Shocks & 0.95 & 0.71 & 2.76 & -0.52 & 0.67 & 0.48 \\
\hline Small Country & DA & $\mathbf{C}$ & $\mathbf{I}$ & NX & TOT & NXQTY \\
\hline Data & 1.12 & 0.77 & 2.62 & -0.17 & -0.22 & -0.19 \\
\hline Benchmark & 0.79 & 0.45 & 2.62 & 0.37 & 0.88 & 0.93 \\
\hline $\begin{array}{l}\text { Note. DA = Domes } \\
\text { Exports over GDP, N } \\
\text { of } 100 \text { simulations of } \\
\text { all simulations, capita } \\
\text { output. }\end{array}$ & $\begin{array}{l}\text { sorption, C } \\
=\text { Real Ne } \\
100 \text { quarte } \\
\text { tment cost }\end{array}$ & $\begin{array}{l}\text { Consum } \\
\text { xports o }\end{array}$ & $\begin{array}{l}\text { n, I I In } \\
\text { Real GD } \\
\text { ng HP fil } \\
\text { to reprod }\end{array}$ & $\begin{array}{l}\text { TOT }= \\
\text { tics for } t \\
\text { othing pa } \\
\text { olatility }\end{array}$ & $\begin{array}{l}\text { ns of Tra } \\
\text { nodel ref } \\
\text { neter eque } \\
\text { nvestmen }\end{array}$ & $\begin{array}{l}\mathrm{le}, \mathrm{NX}=\mathrm{Net} \\
\text { to averages } \\
\text { to } 1600) \text {. In } \\
\text { relative to }\end{array}$ \\
\hline
\end{tabular}


The row labelled "Bond Economy" refers to the case in which only a non-contingent bond is internationally traded. Limiting asset trade to a riskless bond introduces non-stationarity in bond holdings. Following Schmitt-Grohé and Uribe [2003], this experiment includes convex portfolio adjustment costs to induce stationarity. The findings show that there is no significant difference between bond economy and complete markets. Since the work by Cole and Obstfeld [1991], it is well known that in this class of models one internationally traded bond is enough to achieve allocation similar to the complete market case. Positive productivity shocks in one country translate into movements in opposite direction of the terms of trade, so that relative wealth is not affected ${ }^{11}$. I also experiment with different parameters for the portfolio adjustment cost function (as a proxy for frictions in allocating funds across countries) without finding significant differences.

The response of the terms of trade to changes in relative productivity depends critically on the elasticity of substitution between intermediates that appears in the Armington CES aggregator. The row "Large Elasticity" shows the results for the case in which this elasticity takes value of 2.5 (instead of 1.5 as in the benchmark case). Higher substitutability between intermediates translates into lower response of the terms of trade. At this value, net exports are already procyclical. In the limiting case of perfect substitutability, this economy resembles a one-good economy and, not surprisingly, net exports are systematically procyclical (results are not reported for convenience).

The "Persistent" experiment refers to the case in which the parameters of the productivity process are such that there is no spillover effect and the autoregressive coefficients equal 0.99 . Under this parametrization we would expect a larger response of imports, given that agents in both countries would like to take advantage of the persistent investment possibilities available where the shock hits. As discussed before, however, this mechanism would imply that the response of investment, not consumption, would be stronger. After reproducing the volatility of investment as in the data, the response of consumption is still too small and net exports are countercyclical because of terms of trade effect. The net balance of trade in goods is still procyclical.

\footnotetext{
${ }^{11}$ See also Baxter and Crucini [1995] and Heathcote and Perri [2002] on the same point.
} 
Introducing an additional source of fluctuations through government spending shocks does not affect the findings. In the row "Two Shocks", I consider shocks to both productivity and government purchases. Following Backus et al. [1994], government purchases are highly persistent and do not have significant spillover effects, so that the bivariate process governing these shocks has an autoregressive matrix $\mathbf{B}=\operatorname{diag}(0.95,0.95)$, innovations uncorrelated across countries and standard deviations of 0.004 . In most dimensions, the properties of the theoretical economy with two shocks are similar to those in the benchmark economy.

The bottom part of the table studies the implications of varying country size, so that a small country (Canada) trades with the rest of the world. The "Data" row refers to the properties of the data for Canada, while the "Benchmark" row shows the simulations. The data confirm the tight link between countercyclical net exports on one side and volatility of domestic spending relative to output on the other side. The simulations, instead, confirm the tendency for the model to produce procyclical trade balance. In fact, net exports are systematically procyclical, the volatility of consumption being much lower than in the data (0.45 vs 0.77$)$.

In conclusion, this section has shown that the two-country DSGE models à la BKK deliver countercyclical net exports through large price effect, which is counterfactual. Further, the robustness of this result is limited to a small set of parameters values (low elasticity of substitution and same country size). These findings indicate that the dynamics of quantities in the model is primarily determined by the consumption smoothing motive, thus generating procyclical net savings.

\section{Introducing GHH preferences}

In this section I show that introducing home production in the two-country framework enables the model to reproduce countercyclical net exports while providing a new interpretation of this phenomenon. I model home production by use of GHH preferences, as proposed by Greenwood, Hercowitz and Huffman [1988]. The advantage of this reduced form approach, compared to a 
fully specified home sector, is that it allows solve the model for market quantities only.

An extensive literature has recently incorporated household production into DSGE models, primarily motivated by two considerations. From the inputs perspective, there is large evidence on the importance of the allocation of time between market and non-market activities. From the output perspective, we observe a high degree of cyclicality in market consumption of goods and services that are substitutes for home production (such as eating at restaurant, child-care, housecleaning... $)^{12}$.

This evidence suggests that there is a large reallocation of resources across market and nonmarket sectors at business cycle frequency. GHH preferences capture this tradeoff as driven primarily by changes in market technology relative to home technology. Suppose, for example, that the economy experiences a positive productivity shocks in the market technology. The increase in market wages induces households to supply more labor in the market, substituting away from home production. The reduction in hours worked in the home sector translates into less production of home goods which is replaced by an increase in consumption of market goods. As a result, booms are associated with larger response in market consumption than in the standard one sector model.

The introduction of home production in studies of international business cycles is not novel. In the small open economy literature, Correia et al. [1992] show that GHH preferences are needed to be consistent with countercyclical net exports ${ }^{13}$. The application to the two-country two-good model shows that such a mechanism is necessary in a more general environment such as the BKK model. As illustrated above, the BKK set up includes the small open economy model as a limiting case in which the size of one country shrinks relative to the other and the elasticity of substitution between traded goods is large (i.e. there is only one good).

There have been also few attempts to introduce home production in the two-country envi-

\footnotetext{
${ }^{12}$ Standard references in the home production literature include Benhabib et al. [1991], Greenwood and Hercowitz (1991), McGrattan et al. [1993].

${ }^{13}$ As a matter of fact, GHH preferences are nowadays common assumption in this literature. See, for example, Mendoza [1991], Schmitt-Grohé and Uribe [2003], Neumayer and Perri [2005].
} 
ronment. Canova and Ubide [1998], for example, explicitly model a home production sector. Devereux et al. [1992] adopt a non-separable utility function similar to GHH. The goal of these studies, however, is to show that adding home production improves the model's predictions in terms of international correlations. In this paper, I argue that home production addresses a more fundamental issue related to the BKK model, that is the ability of the model to generate countercyclical net exports without relying on counterfactual terms of trade effects. The BKK model has been for a long time considered as a benchmark because it has provided a theoretical interpretation of countercyclical net exports: they reflect in large part the dynamics of capital. My findings, on the contrary, emphasize the role played by consumption fluctuations in interpreting this feature of the data. Home production provides a rationale for these fluctuations.

\subsection{Simulation Results with GHH Preferences}

Under GHH preferences, the momentary utility takes functional form of the type

$$
U(C, N)=\frac{\left[C-\psi N^{\nu}\right]^{1-\gamma}}{1-\gamma}
$$

where $\nu>1, \psi>0$. Benhabib et al. [1991] show that this utility function can be obtained analytically as a reduced form case from a model that expands the commodity space to include home activities ${ }^{14}$. An interesting feature of this utility function is that despite leisure being a normal good, there is no income effect on (market) labor supply. The underlying home production structure, however, provides a rationale for this property: during booms, agents reduce hours worked at home in favor of market hours. Greenwood et al. [1988], in their original contribution, explore the quantitative implications of such property in an environment in which shocks to the marginal efficiency to investment are important for business cycle fluctuations.

As in the previous section, I find the solution of the model by linearizing around the nonstochastic steady state. The parameter values are the same as before. However, two additional

\footnotetext{
${ }^{14}$ The relevant assumption is that home and market consumption are close substitutes. Benhabib et al. [1991] and Eichenbaum and Hansen [1990] provide evidence in favor of this assumption.
} 
parameters need to be calibrated, namely $\psi$ and $\nu$. The parameter $\nu$ governs the elasticity of labor supply and is calibrated so that this elasticity is the same as in the Cobb-Douglas case. In particular, under Cobb-Douglas preferences the elasticity of labor supply (with marginal utility held constant) is equal to

$$
\varepsilon_{C D}=\frac{(1-N)[1-\mu(1-\sigma)]}{\sigma N}
$$

while the value for this elasticity implied by GHH preferences is

$$
\varepsilon_{G H H}=\frac{1}{\nu-1}
$$

Once $\nu$ is calculated, $\psi$ can computed from the static first order condition so that in steady state the household allocates one third of her time endowment to market activities.

Figure 2 reports the impulse responses for the relevant variables in country 1 after it experiences a positive productivity shocks. The top panels illustrates that net exports are countercyclical and the terms of trade procyclical. However, with GHH preferences net exports are countercyclical mainly because of changes in the net trade of goods (NXQTY). As a matter of fact, the impulse responses of these two variables are basically aligned.

Figure 2 also presents the response of domestic spending together with output (bottom right panel). Contrary to the case with isoelastic preferences, under GHH preferences domestic absorption responds much more than output to productivity shocks: the ratio between the impact coefficients of domestic absorption and output is around 1.14 under GHH preferences, while it was 0.98 with isoelastic preferences. Given that the response of investment is kept constant across experiments (though in a unconditional sense), the larger response of domestic spending to productivity shocks must originate from the dynamics of consumption. 
Fig. 2. BKK with GHH preferences: Impulse response for $1 \%$ productivity shock in country 1
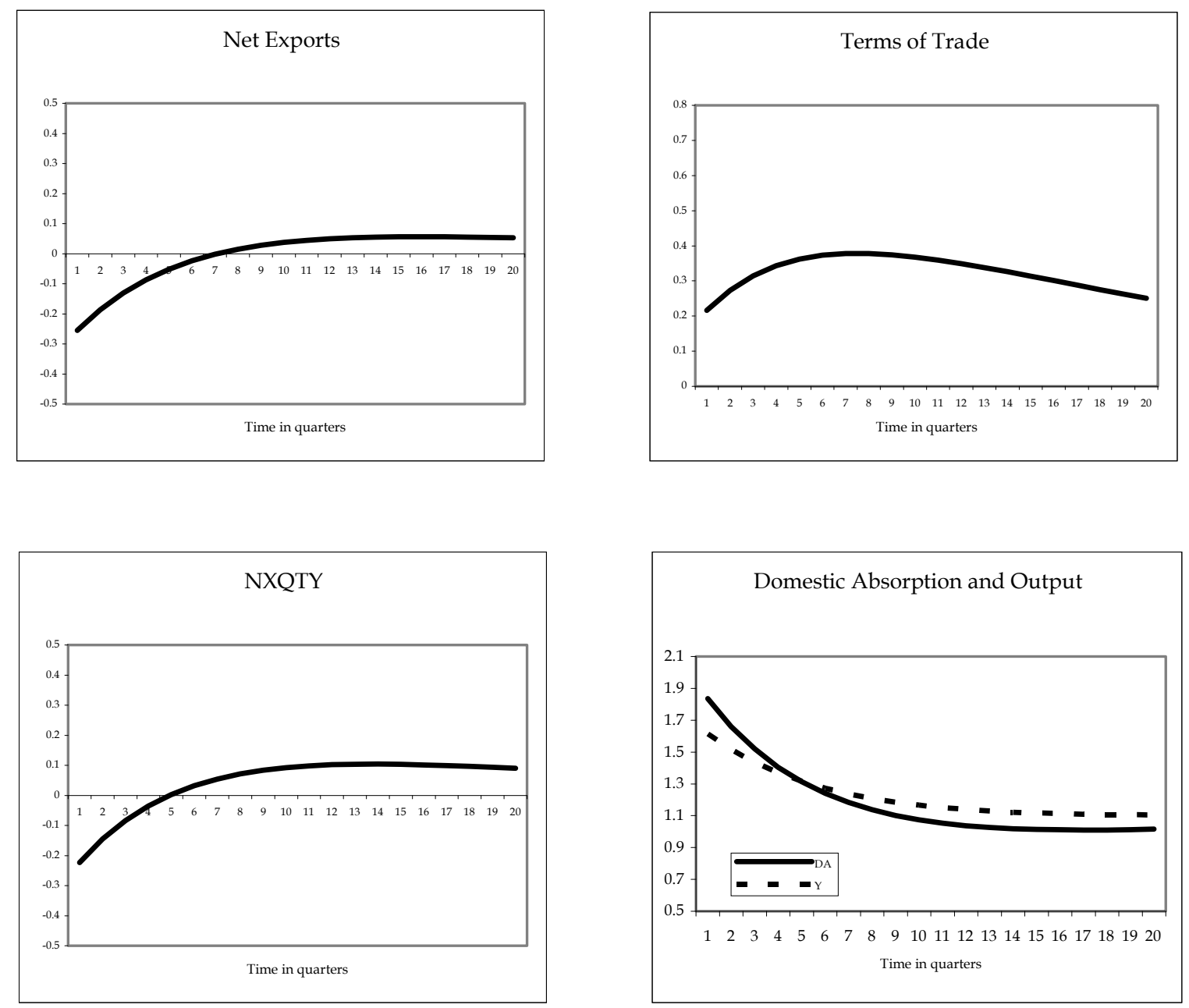

Simulations confirm these findings. Table 4 compares the performance of the BKK model under isoelastic preferences and under GHH preferences. The first striking difference is the increase in the volatility of domestic absorption relative to the benchmark case: under $\mathrm{GHH}$ preferences, the volatility of domestic spending is indeed greater than output volatility, as in the data. This effect is due to the increase in consumption volatility relative to output volatility.

In terms of correlation, net exports are countercyclical in both cases. However, with GHH preferences the net flow of goods across countries ( $N X Q T Y)$ in countercyclical as well, as in the data. The model with GHH preferences, in other words, is able to reproduce countercyclical 
net exports without resorting to counterfactual terms of trade effects.

Table 4. Symmetric BKK with GHH Preferences

\begin{tabular}{cccc}
\hline \hline & Data & BKK & GHH \\
\hline Std Dev relative to Output & & & \\
DA & 1.12 & 0.98 & 1.13 \\
C & 0.81 & 0.66 & 0.82 \\
$\mathbf{X}$ & 2.76 & 2.76 & 2.76
\end{tabular}

Correlation with Output

NX $-0.51 \quad-0.61 \quad-0.55$

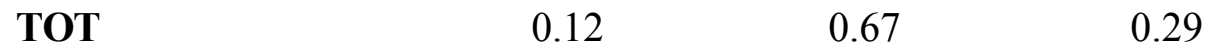

$\begin{array}{llll}\text { NXQTY } & -0.41 & 0.23 & -0.53\end{array}$

Note. $\mathrm{DA}=$ Domestic Absorption, $\mathrm{C}=$ Consumption, $\mathrm{I}=$ Investment, $\mathrm{TOT}=$ Terms of Trade, $\mathrm{NX}=$

Net Exports over GDP, NXQTY = Real Net Exports over Real GDP. Statistics for the model refer to averages of 100 simulations of length 100 quarters after applying HP filter with smoothing parameter equal to 1600. In all simulations, capital adjustment costs are included to reproduce the volatility of investment relative to output.

The mechanism underlying GHH preferences works as follows. After a positive productivity shocks, households reallocate labor supply from the home sector into the market sector because of the increase in the wage rate. The reduction in hours worked at home and, as a consequence, in consumption of home goods induce agents to increase their consumption of goods produced in the market. This effect generates imports of goods to exceeds exports, so that the trade balance is countercyclical.

The economics behind home production is closely related to the introduction of a non-tradeable sector into the original BKK formulation. However, there are two arguments that make the choice 
of home production vis-à-vis a standard non-tradeable sector preferable. First, GHH preferences introduce a non-tradeable good that is close substitute for tradable consumption. While the empirical evidence suggest that there is a high degree of substitution between home and market consumption, this is not the case for nontraded goods. Stockman and Tesar [1995], for example, estimate an elasticity of substitution between traded and nontraded goods equal to 0.44 . In general, this elasticity is estimated to be less than one.

A second reason to prefer home production to non-tradeable production stems from the twosectors implications of the model. In a two-sector environment, in fact, changes to the relative efficiency of production induce large reallocation of inputs across sectors. This is, at the end, the mechanism at work with home production. In the case of a non-tradeable sector, however, this mechanism would generate negative inputs comovements across sectors belonging to the same economy, whereas business cycles data display high positive comovement across sectors. The negative correlation between home and market production generated by the model is, on the other hand, a desirable property because consistent with the empirical evidence.

Overall, these results provide additional support to the quantitative importance of the substitution between home and market activities at business cycle frequency. The increase in the responsiveness of market consumption to expansions in market economic activity helps explaining why we observe a strong relationship between income and imports. This analysis suggests also that not the dynamics of capital, but the response of consumption to income shocks represent a fundamental determinant of the cyclical fluctuations of the trade balance.

\subsection{Sensitivity Analysis}

This section provides additional evidence in favor of the introduction of GHH preferences into the BKK model by performing sensitivity analysis with respect to two key parameters, namely the elasticity of substitution between traded goods and country size.

Table 5 reports sensitivity analysis to different values for the elasticity of substitution between intermediate goods. As already mentioned, this parameter is important because it affects the 
volatility of the terms of trade and, as a direct consequence, the countercyclicality of net exports.

Table 5 illustrates that our findings are not sensitive to the particular value for this parameter. In all cases, countercyclical net exports are associated with countercyclical net trade in goods and domestic absorption is more volatile than output because of sufficient volatility in consumption.

Table 5. BKK with GHH Preferences: Sensitivity to Elasticity of Substitution

\begin{tabular}{llllllll}
\hline \hline Elasticity of Substitution: & 0.5 & 1 & 2 & 5 & 25 & 100 \\
\hline
\end{tabular}

Std Dev relative to Output

$\begin{array}{lllllll}\text { DA } & 1.11 & 1.12 & 1.15 & 1.19 & 1.20 & 1.21 \\ \mathbf{C} & 0.79 & 0.81 & 0.82 & 0.83 & 0.85 & 0.86 \\ \mathbf{X} & 2.74 & 2.74 & 2.74 & 2.74 & 2.74 & 2.74\end{array}$

Correlation with Output

$\begin{array}{ccccccc}\text { NX } & -0.54 & -0.55 & -0.58 & -0.57 & -0.53 & -0.53 \\ \text { TOT } & 0.45 & 0.39 & 0.15 & -0.06 & -0.15 & -0.16 \\ \text { NXQTY } & -0.52 & -0.53 & -0.56 & -0.56 & -0.53 & -0.53\end{array}$

Note. See note Table 4.

It is worth to notice that for large values of this elasticity, the terms of trade become negatively correlated with output, feature that characterizes some countries of Table 2. The intuition for this result can be found by analyzing the linearized expression determining the terms of trade in the model. Appendix B, in fact, presents the derivation of the following relationship

$$
\widehat{t o t}=\eta\left[\phi \widehat{n x q t y}+\left(\widehat{y}_{1}-\widehat{y}_{2}\right)\right]
$$

where both $\eta$ and $\psi$ are positive coefficients. This equation implies that changes in the terms 
of trade are the result of two offsetting forces. The second term $\left(\widehat{y}_{1}-\widehat{y}_{2}\right)$ can be interpreted as a supply effect and captures the idea that productivity shocks alter directly the relative scarcity of goods in the international markets. Hence, positive productivity shocks at home imply that foreign goods become more expensive. The first term $(\widehat{\text { nxqty }})$ represents a shift in domestic aggregate demand (real net exports equal the difference between real output and domestic spending). The cyclical properties of the terms of trade reflect the balancing of these two effects. In the original BKK formulation, the former effect strongly dominates the latter, so that the terms of trade are always procyclical. Adding home production through GHH preferences, instead, makes the response of domestic spending stronger so that, for large values of the elasticity of substitution between intermediates, the terms of trade turn out to be countercyclical.

As a final experiment, Table 6 shows the effects of varying both the elasticity of substitution between intermediates and country size at the same time. For simplicity, only the correlation between net exports and output (NX) and between net trade in goods and output (NXQTY) are reported.

Table 6. Small Country and GHH Preferences: Sensitivity to Elasticity of Substitution

\begin{tabular}{|c|c|c|c|c|c|c|c|}
\hline \multirow[b]{2}{*}{$\begin{array}{l}\text { Correlation } \\
\text { with Output }\end{array}$} & & \multicolumn{2}{|c|}{$\boldsymbol{\sigma}_{R O W}=5$} & \multicolumn{2}{|c|}{$\boldsymbol{\sigma}_{R O W}=25$} & \multicolumn{2}{|c|}{$\boldsymbol{\sigma}_{R O W}=100$} \\
\hline & & $\mathbf{N X}$ & NXQTY & $\mathbf{N X}$ & NXQTY & $\mathbf{N X}$ & NXQTY \\
\hline \multirow{4}{*}{$\sigma_{C A N}=$} & 0.5 & -0.43 & -0.34 & -0.33 & -0.31 & -0.29 & -0.28 \\
\hline & 1 & -0.43 & -0.34 & -0.32 & -0.30 & -0.29 & -0.28 \\
\hline & 5 & -0.36 & -0.32 & -0.32 & -0.30 & -0.29 & -0.28 \\
\hline & 25 & -0.32 & -0.30 & -0.28 & -0.26 & -0.26 & -0.26 \\
\hline
\end{tabular}

Note. See note Table 4.

Table 6 confirms that results are robust to changes in the elasticity of substitution between intermediates in the small country environment as well, thus increasing the robustness of the 
original BKK formulation along this dimension. In addition, these results demonstrate that the two-country model with GHH preferences can provides the basic analytical framework to study business cycles in small open economies, which is richer than the conventional framework adopted in the literature.

\subsection{Some final remarks}

This section explores the implications of GHH preferences for international prices ${ }^{15}$. As Backus et al. [1995] point out, two-country versions of real business cycle models generate extremely low variability of the terms of trade compared to what we observe in the data ("price variability anomaly"). Moreover, it is well known that the real exchange rate is volatile and persistent in the data, feature difficult to reproduce in theoretical economies.

Table 7 compares the volatility of international prices under the original BKK formulation and under GHH preferences. The data, which for simplicity refer to U.S. only, reveal two important features: the terms of trade (TOT) are more volatile than output and the real exchange rate ${ }^{16}$ $(R E R)$ is extremely volatile (more than the terms of trade).

Under the standard BKK formulation, the terms of trade are half as volatile as in the data. Under GHH preferences, the model performs poorly in this dimension, the volatility of terms of trade being one fourth of the volatility observed in the data. Our discussion of equation (22) provides an intuition for this failure. Terms of trade movements reflect the balance between two opposing forces: relative scarcity of intermediates due to changes in production and relative shift in domestic spending. Under GHH preferences, domestic absorption responds more to productivity shocks than under isoelastic preferences, thus offsetting the relative scarcity effect embedded in the model. As a consequence, the terms of trade fluctuates even less than in the original BKK formulation. The counterpart of this effect is that the model generates more realistic dynamics in goods trade: not only net exports are countercyclical, but the volatility of net exports is also

\footnotetext{
${ }^{15}$ I would like to thank an anonymous referee for suggesting to include this section and for useful comments.

${ }^{16}$ The series for the U.S. exchange rate is a trade-weighted measure of the real value of the US dollar reported by the Boad of Governors (Board Index).
} 
closer to the empirical volatility. Under BKK, instead, net exports exhibit very low variability.

Table 7. International Prices

\begin{tabular}{cccc}
\hline \hline $\begin{array}{c}\text { Std Dev relative } \\
\text { with Output }\end{array}$ & Data & BKK & GHH \\
TOT & 1.12 & 0.57 & 0.30 \\
RER & 2.89 & 0.39 & 0.21 \\
$\mathbf{N X}$ & 0.30 & 0.07 & 0.18 \\
NXQTY & 0.23 & 0.05 & 0.17 \\
\hline \hline
\end{tabular}

Note. See note Table 5. RER = real exchange rate

Turning to the real exchange rate, Heathcote and Perri $[2002]^{17}$ show that in this class of models there is a linear relationship between terms of trade and real exchange rate, that is

$$
\widehat{t o t}=\frac{1}{1-2 i m} \widehat{r e r}
$$

where $i m$ is the import share. Given that the import share is between 0 and 1, this relationship implies that the real exchange rate is always less volatile than the terms of trade. More importantly for our purposes, the above relationship depends only on the production structure and is independent of preferences and asset markets assumptions. Not surprisingly, then, the model under GHH preferences preserves the ranking of volatilities implicit in the BKK model, thus making the real exchange rate implications of the model still at odds with the data.

In conclusion, under GHH preferences the model generates international business cycles in line with the data with respect to the overall dynamics of quantities. The major discrepancy between theory and data concerns the variability of international prices.

\footnotetext{
${ }^{17}$ See equation (A19) in their Appendix A.
} 


\section{Conclusions}

This paper challenges the conventional wisdom that trade fluctuations reflect, to a large extent, the dynamics of capital formation typical of two-country models à la Backus et al. [1992, 1994]. After replicating the volatility of investment, theoretical economies generate countercyclical net exports through large terms of trade effect, while the net flow of goods is indeed procyclical. In the data, however, the latter is countercyclical, indicating that there is a strong relationship between income and imports.

Countercyclical net exports have a counterpart in terms of volatilities: domestic absorption is more volatile than output. I use this observation to point out that the model delivers too little variability in consumption or, in other words, consumption smoothing is the main force governing the dynamics of trade.

I then introduce home production through $\mathrm{GHH}$ preferences in the standard two-country framework. Productivity shocks, by altering the relative efficiency between home and market activities, are associated with stronger response in market consumption so that net exports are countercyclical because of imports exceeding exports, as in the data. These findings suggest that countercyclical net exports reflect primarily the dynamics of consumption.

The major discrepancy between theory and data concerns the volatility of international prices. Under GHH preferences, the model successfully reproduces the cyclical properties of quantities, including the volatility of trade variables. The implications in terms of variability of the terms of trade and the real exchange rate, instead, are in contrast with the data. I leave the study of this important issue to future research. 


\section{Appendix A. Data}

For all countries, data are from OECD Quarterly National Accounts at current and constant prices and cover the sample 1980:1-2004:2. The terms of trade are constructed as the ratio of import price index (import at current prices over import at constant prices) and export price index (export at current price over export at constant prices). Employment is the series Civilian Employment from OECD-Main Economic Indicators. Whenever a significant seasonal component was found, I deseasonalize the series using Census X-12 routine. To compute all statistics, I transform the series using the natural logarithm and then apply HP filter with smoothing parameter of 1600 except for net exports, for which I do not take the logarithm.

The series for Rest of the World is an aggregate of EU-15, Japan and U.S. The OECD computes series for EU-15 in dollars using PPP-adjusted indices. For Japan, I first transform all series into year 2000 yen because the Japanese base year is 1995 and then use 2000 PPP index to convert them into dollars. I finally use 2000 population 15-64 as weight and construct aggregate series. I experiment using 2000 PPP-adjusted GDP per capita as weights, but the results are not affected.

\section{Appendix B. Linearization}

I compute the solution of the model by calculating the non-stochastic steady state and linearizing around this point. In solving for the linearized equations, I make large use of the properties of constant returns to scale functions. In particular, given the function $G(a, b)$ homogenous of degree one, it can easily be shown that the following properties are satisfied:

[1] $G()=.G_{a} a+G_{b} b$

[2] $0=G_{a a} a+G_{a b} b$

[3] $\sigma=\frac{G_{a} G_{b}}{G_{a b} G}$, where $\sigma$ is the elasticity of substitution between $a$ and $b$.

Given that the Armington aggregator is homogenous of degree one, it is immediate to calcu- 
late its $\log$-linearize version as ${ }^{18}$

$$
\widehat{G(.)}=\frac{\bar{G}_{a} \bar{a}}{\bar{G}} \hat{a}+\frac{\bar{G}_{b} \bar{b}_{\hat{b}}}{\bar{G}}=\left(1-i m_{1}\right) \hat{a}_{1}+i m_{1} \hat{b}_{1}
$$

where $i m$ is the import share. This expression shows that $\varpi$ is calibrated by computing import shares from the data.

The trade balance over GDP is defined in equation (15) and has the following linear representation

$$
\widehat{n x}=i m_{1}\left[\hat{a}_{2}-\hat{b}_{1}-\hat{p}\right]
$$

Notice that changes in net exports are determined by changes in quantities (exports and imports) and prices (terms of trade). I isolate the first component by defining the variable NXQTY as the difference in export minus import evaluated at steady state prices, which has an empirical counterpart in the same variables measured in constant prices. Hence the variable NXQTY, defined in equation (16) has the following linear approximation

$$
\widehat{n x q t y}=i m_{1}\left[\hat{a}_{2}-\hat{b}_{1}\right]
$$

Market clearing condition for good $A$, equation (10), yields

$$
\hat{y}_{1}=\left(1-i m_{1}\right) \hat{a}_{1}+i m_{1} \hat{a}_{2}
$$

We can observe that expression (B.3) can be obtained by combining expression (B.1) and (B.4), that is

$$
\widehat{n x q t y}=\hat{y}_{1}-\hat{G}_{1}=i m_{1}\left[\hat{a}_{2}-\hat{b}_{2}\right]
$$

Finally, I derive expression (26) for the terms of trade as follows. The definition of the terms of trade is

$$
P=\frac{G_{b}}{G_{a}}
$$

\footnotetext{
${ }^{18}$ In what follows I denote with an hat percentage deviations from steady state and with a bar steady state values. I present the equation only for country 1 , but analogous expressions apply to country 2 .
} 
whose linear approximation is

$$
\widehat{p}=\frac{1}{\sigma}\left[\hat{a}_{1}-\hat{b}_{1}\right]
$$

Combining (B.7), (B.5), (B.4) and its analogous for country 2 we obtain

$$
\hat{p}=\eta\left[\phi n x q t y+\left(y_{1}-y_{2}\right)\right]
$$

where $\eta=\frac{1}{2 \sigma\left(1-i m_{1}\right)}$ and $\phi=\frac{1-2 i m_{1}}{i m_{1}}$.

\section{Appendix C. Benchmark Parameter Values}

Table 8 reports the parameter values used in the benchmark simulation. Preference and technology parameters are from the original BKK work and are common across experiments. The bottom panel of the table presents the parameters that differ as country size varies: trade shares and productivity process. Under "BKK" I report the values used in the original BKK work, while under "Small Country" I present the estimates for Canada (trading with a rest of the world aggregate). I choose Canada because it has been commonly used in studies of business cycles in small open economies.

I calibrate the share in the Armington aggregator $\varpi_{i}$ for Canada so that the implied import shares are consistent with the average values over the sample 1980:1-2004:1 (this value is 0.32), while for the rest of the world I arbitrarily set this value equal to 0.001 so that it resembles a closed economy. The corresponding value used by BKK is 0.15 .

I compute the two sequences of productivity shocks $z_{i t}$ using the expression

$$
z_{i t}=\ln \left(y_{i t}\right)-(1-\theta) \ln \left(n_{i t}\right)
$$

where $y_{i t}$ is real output and $n_{i t}$ is total employment. Given the two sequences of technology shocks, I then estimate a 2 x 2 VAR process. For the BKK case, the estimates did not differ significantly from their original values, despite the use of a different sample ${ }^{19}$. I decided to use

\footnotetext{
${ }^{19}$ The OECD computes quarterly time series for EU-15 over the sample 1980:1-2002:4, while data in the BKK paper covered the sample 1970:1-1986:4 for a much smaller group of European countries.
} 
the latter for easy of comparison. For the small country case, I set the spillover parameter from Canada to the rest of the world to be equal to zero because of lack of statistical significance ${ }^{20}$. Hence, the coefficients on the main diagonal are also the eigenvalues associated with the process, determining the persistence of the solution associated with two sequences of shocks.

The last row of the table reports the ratio of population between countries. I use working age population in the year 2000 for Canada and for the rest of the world aggregate to calibrate this parameter. This parameter does not affect the simulation under complete markets, but only the bond economy case.

Table 8. Benchmark Parameters

\begin{tabular}{|c|c|c|c|c|}
\hline Preferences & & $\beta=0.99$ & $\mu=0.34$ & $\gamma=2.0$ \\
\hline \multirow[t]{2}{*}{ Technology } & & $\theta=0.36$ & $\delta=0.025$ & $\sigma=1.5$ \\
\hline & & BKK & & Small Country \\
\hline \multirow[t]{2}{*}{ Trade shares } & & $i m_{1}=0.15$ & & $i m_{1}=0.320$ \\
\hline & & $i m_{2}=0.15$ & & $i m_{2}=0.001$ \\
\hline \multirow[t]{5}{*}{ Productivity } & & & & \\
\hline & Transition Matrix & $\begin{array}{ll}0.906 & 0.088 \\
0.088 & 0.906\end{array}$ & & $\begin{array}{cc}0.959 & 0.041 \\
0 & 0.998\end{array}$ \\
\hline & Std Dev innovations & $\sigma_{1}=0.00852$ & & $\sigma_{1}=0.0691$ \\
\hline & & $\sigma_{2}=0.00852$ & & $\sigma_{2}=0.0499$ \\
\hline & Corr innovations & $\sigma_{1,2}=0.2580$ & & $\sigma_{1,2}=0.1288$ \\
\hline Population & & $\frac{N_{1}}{N_{2}}=1.00$ & & $\frac{N_{1}}{N_{2}}=0.04$ \\
\hline
\end{tabular}

\footnotetext{
${ }^{20}$ The estimated value turned out to be extremely small and insignificant. The p-value for Granger causality test is around 40 percent for this coefficient.
} 


\section{References}

[1] Aguiar, M. and G. Gopinath, [2004], "Emerging Market Business Cycles: The Cycle is the Trend", working paper.

[2] Backus, D. and P. Kehoe [1992], "International Evidence on the Historical Properties of Business Cycles", American Economic Review, September, 82, 864-888.

[3] Backus, D., P. Kehoe and F. E. Kydland [1994], "Dynamics of the Trade Balance and the Terms of Trade: The J-Curve?", American Economic Review, March, 84, 84-103.

[4] Backus, D., P. Kehoe and F. E. Kydland [1995], "International Business Cycles: Theory and Evidence", in Frontiers of Business Cycle Research, ed. T. F. Cooley. Princeton University Press. Princeton, pp.331-356.

[5] Baxter, M. and M. Crucini [1995], "Business Cycles and the Asset Structure of Foreign Trade", International Economic Review, 36, 821-854.

[6] Baxter, M. and U. Jermann [1999], "Household Production and The Excess Sensitivity of Consumption to Current Income", American Economic Review, September, 89, 902-920.

[7] Benhabib, J., R., Rogerson and R. Wright, [1991], "Homework in Macroeconomics: Household Production and Aggregate Fluctuations', Journal of Political Economy, December, 1991, 99(6), pp. 1167-87.

[8] Chari, V.V., P.J. Kehoe and E.R. McGrattan [2002], "Can Sticky Price Models Generate Volatile and Persistent Real Exchange Rates?", Review of Economic Studies, 69, 533-563.

[9] Cole, H. and M. Obstfeld [1991], "Commodity Trade and International Risk Sharing: How Much Do Financial Markets Matter?", Journal of Monetary Economics, 28, 3-24.

[10] Cooley, T. [1995], Frontiers of Business Cycle Research, Princeton University Press. Princeton, New Jersey. 
[11] Cooley, T. and E. Prescott [1995], "Economic Growth and Business Cycles", in Frontiers of Business Cycle Research, ed. T. F. Cooley. Princeton University Press. Princeton, New Jersey.

[12] Correia, I., J. C. Neves and S. Rebelo [1995], " Business Cycles in Small Open Economies", European Economic Review 39, 1089-1113.

[13] Dantine, J.P. and J.B. Donaldson [1993], "Methodological and Empirical Issues in Real Business Cycle Theory", European Economic Review, January 1993, 37(1), pp. 1-35.

[14] Devereux, M., A. Gregory and G. Smith [1992], "Realistic cross-country consumption correlations in a two-country, equilibrium, business cycle model", Journal of International Money and Finance.

[15] Eichenbaum, M. and L.P. Hansen [1990], "Estimating Models with Intertemporal Substitution Using Aggregate Time Series data", Journal of Business and Economic Statistics, 8:53-69.

[16] Greenwood, J., Z. Hercowitz and G. W. Huffman [1988], "Investment, Capacity Utilization and Real Business Cycle", American Economic Review, June 1988, 78, 402-17.

[17] Heathcote, J. and F. Perri [2002], "Financial Autarky and International Business Cycles", Journal of Monetary Economics, 49, 601-627.

[18] Kehoe, P. and F. Perri [2002], "International Business Cycles with Endogenous Incomplete Markets", Econometrica, 70/3, 907-928.

[19] Mendoza, E., [1991], "Real Business Cycle in a Small Open Economy", American Economic Review, September, 81, 797-818.

[20] McGrattan, E., R., Rogerson and R. Wright, [1997], "An Equilibrium Model of the Business Cycle with Household Production and Fiscal Policy", International Economic Review, September, May 1997, 38(2), pp.267-290. 
[21] Neumeyer, P. A. and F. Perri [2005], "Real Business Cycles in Emerging Markets: The Role of Interest Rates", Journal of Monetary Economics, 52, 345-380.

[22] Sachs, J.D. [1981], "The Current Account and Macroeconomic Adjustment in the 1970s", Brooking Papers on Economic Activity, 201-268.

[23] Schmitt-Grohé, S. and M. Uribe [2003], "Closing Small Open Economy Models", Journal of International Economics, 61, 163-185.

[24] Stockman, A. C. and L. Tesar [1995], "Tastes and Technology in a Two-Country Model of Business Cycle: Explaining International Comovements", American Economic Review, March 1995, 85, 168-185.

[25] Uhlig, Harald [1999], "A Toolkit for Analyzing Nonlinear Dynamic Stochastic Models Easily", in Ramon Marimon and Andrew Scott (eds). Computational Methods for the Studies of Dynamic Economies. Oxford: Oxford University Press. 